\title{
Anticancer Effects of the Corchorus olitorius Aqueous Extract and Its Bioactive Compounds on Human Cancer Cell Lines
}

\author{
John Paul Sese Tosoc ${ }^{1,2, *}$, , Olga Macas Nuñeza ${ }^{1}$, Thangirala Sudha ${ }^{2}$, Noureldien H. E. Darwish ${ }^{2,3}$ \\ and Shaker A. Mousa ${ }^{2}(\mathbb{D}$ \\ 1 Department of Biological Sciences, College of Science and Mathematics, Mindanao State University-Iligan \\ Institute of Technology, Iligan City 9200, Philippines; olga.nuneza@g.msuiit.edu.ph \\ 2 Pharmaceutical Research Institute, Albany College of Pharmacy and Health Sciences, \\ Rensselaer, NY 12144, USA; sudha.thangirala@acphs.edu (T.S.); noureldien.darwish@acphs.edu (N.H.E.D.); \\ shaker.mousa@acphs.edu (S.A.M.) \\ 3 Hematology Unit, Clinical Pathology Department, Faculty of Medicine, Mansoura University, \\ Mansoura 35516, Egypt \\ * Correspondence: johnpaul.tosoc@g.msuiit.edu.ph; Tel.: +63-083-520-7969
}

Citation: Tosoc, J.P.S.; Nuñeza, O.M.; Sudha, T.; Darwish, N.H.E.; Mousa, S.A. Anticancer Effects of the Corchorus olitorius Aqueous Extract and Its Bioactive Compounds on Human Cancer Cell Lines. Molecules 2021, 26, 6033. https://doi.org/ $10.3390 /$ molecules 26196033

Academic Editor: José Rubén Tormo

Received: 8 September 2021

Accepted: 29 September 2021

Published: 5 October 2021

Publisher's Note: MDPI stays neutral with regard to jurisdictional claims in published maps and institutional affiliations.

Copyright: (c) 2021 by the authors. Licensee MDPI, Basel, Switzerland. This article is an open access article distributed under the terms and conditions of the Creative Commons Attribution (CC BY) license (https:/ / creativecommons.org/licenses/by/ $4.0 /)$.

\begin{abstract}
Corchorus olitorius is a common, leafy vegetable locally known as "Saluyot" in the Philippines. Several studies have reported on its various pharmacological properties, such as antioxidant, anti-inflammatory, analgesic, and anticancer properties. However, little is known about its effects on angiogenesis. This study aimed to evaluate the anticancer properties, such as the antiproliferative, anti-angiogenic, and antitumor activities, of the $\mathrm{C}$. olitorius aqueous extract (CO) and its bioactive compounds, chlorogenic acid (CGA) and isoquercetin (IQ), against human melanoma (A-375), gastric cancer (AGS), and pancreatic cancer (SUIT-2), using in vitro and in ovo biological assays. The detection and quantification of CGA and IQ in CO were achieved using LC-MS/MS analysis. The antiproliferative, anti-angiogenic, and antitumor activities of CO, CGA, and IQ against A-375, AGS, and SUIT-2 cancer cell lines were evaluated using MTT and CAM assays. CGA and IQ were confirmed to be present in CO. CO, CGA, and IQ significantly inhibited the proliferation of A-375, AGS, and SUIT-2 cancer cells in a dose-dependent manner after $48 \mathrm{~h}$ of treatment. Tumor angiogenesis (hemoglobin levels) of A-375 and AGS tumors was significantly inhibited by CO, CGA, IQ, and a CGA-IQ combination. The growth of implanted A-375 and AGS tumors was significantly reduced by CO, CGA, IQ, and a CGA-IQ combination, as measured in tumor weight. Our investigation provides new evidence to show that $\mathrm{CO}$ has promising anticancer effects on various types of human cancer cells. $\mathrm{CO}$ and its compounds are potential nutraceutical products that could be used for cancer treatment.
\end{abstract}

Keywords: functional food; angiogenesis; anticancer; cancer; chlorogenic acid; isoquercetin; Corchorus olitorius; MTT assay; CAM assay

\section{Introduction}

Cancer remains one of the leading causes of death worldwide. One mechanism involved in cancer development is angiogenesis, which is the formation of new blood vessels. Angiogenesis is a normal biological process that plays a pivotal role during embryonic development, wound healing, and the menstrual cycle [1-4]. However, under pathological conditions, it partakes in an array of diseases in addition to cancer, such as diabetic retinopathy, peripheral vascular disease, endometriosis, tissue regeneration, atherosclerosis, obesity, and rheumatoid arthritis [5].

During tumor growth, angiogenesis ensures the supply of sufficient oxygen and fundamental nutrients to cancer cells and tissues [6,7]. Angiogenesis is regulated by various pro-angiogenic factors such as vascular endothelial growth factor (VEGF), platelet-derived 
growth factor (PDGF), basic fibroblast growth factor (bFGF), transforming growth factorbeta (TGF- $\beta$ ), angiogenin, and interleukin- 8 (IL-8). These factors promote endothelial cell stimulation, proliferation, and invasion, resulting in the excessive growth of new capillaries in the tumor [8,9]. VEGF is one of the most important regulators of angiogenesis [10]. It is secreted from cancer and stromal cells in the tumor microenvironment to promote the growth and migration of vascular endothelial cells and the permeability of blood vessels [11].

Corchorus olitorius Linn, family Malvaceae, is a common leafy vegetable locally known as "Saluyot" in the Philippines. It is considered by the Philippines Department of Science and Technology [12] as a functional food that provides health benefits beyond an essential nutrient function, such as for reducing the occurrence of lifestyle-related diseases including obesity, atherosclerosis, cardiovascular disease, diabetes, and cancer. Traditionally, C. olitorius has been considered a folk remedy for different illnesses such as diabetes, hypertension [13], aches, pains [14], infertility [15], pimples, wounds, boils, insect bites, and swellings. Original research articles have reported the different pharmacological properties of C. olitorius, which include antioxidant [16], anti-inflammatory [17], antihyperglycemic, and anticancer properties [18].

Polyphenolic compounds are a component of the human diet, and they have various helpful pharmacological properties that have low toxicity [19]. Previous studies have shown that $C$. olitorius leaves contain chlorogenic acid and isoquercetin [20]. Chlorogenic acid is one of the most common polyphenols in the human diet and exhibits many health-promoting benefits [21], such as antioxidant, anti-inflammatory [22], and anticancer benefits [23-27]. Moreover, isoquercetin, also known as isoquercitrin, is a naturally available quercetin glycoside [28-30]. In vitro and in vivo studies of glioma, colon, breast, ovarian, and liver cancer showed that isoquercetin exhibits potent, antiproliferative properties [30,31]. However, the mechanisms of action of these compounds as antitumor agents remain unclear.

In this study, bioactive compounds of $C$. olitorius aqueous leaf extract (CO), namely chlorogenic acid (CGA) and isoquercetin (IQ), were qualitatively and quantitatively identified using LC-MS/MS analysis. The effects on cancer cell proliferation were determined using MTT assay of human melanoma (A-375), gastric (AGS), and pancreatic (SUIT-2) cell lines. The anti-angiogenesis and antitumor activities of CO, CGA, and IQ were also explored in the chick chorioallantoic membrane (CAM) model via A-375 and AGS tumor cell implantation.

\section{Results}

\subsection{Identification and Quantification of Chlorogenic Acid and Isoquercetin}

We first identified and quantified the CGA and IQ contents present in $1 \mathrm{mg} / \mathrm{mL}$ of CO via chromatographic profiling before conducting the bioassays. Using LC-MS/MS analysis, the presence of CGA $(556 \mathrm{ng} / \mathrm{mL})$ and IQ $(168 \mathrm{ng} / \mathrm{mL})$ in the plant extract was confirmed and quantified by comparing their chromatograms (Figure 1A) to the chromatograms of CGA and IQ standards (Figure 1B). 

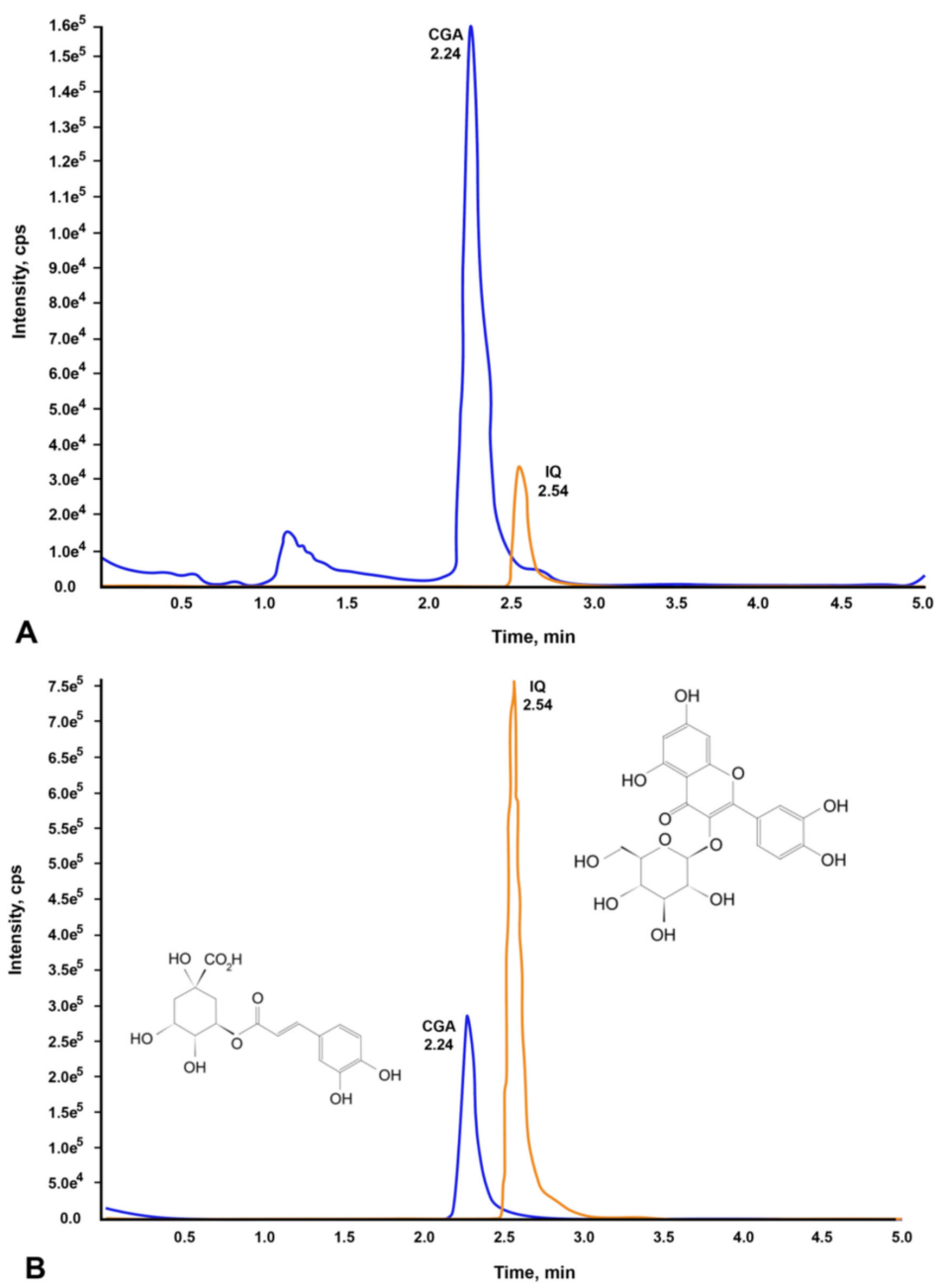

Figure 1. Chromatograms of CGA and IQ found in C. olitorius aqueous extract. (A) CGA and IQ present in CO, and (B) standard compounds (CGA and IQ).

\subsection{CO, CGA, and IQ Inhibited Human Cancer Cells' Proliferation}

SUIT-2, A-375, and AGS cell lines were selected to assess the cytotoxicity activities of CO, CGA, and IQ while using the MTT assay. As shown in Figure 2, these cell lines treated with various concentrations of CO and CGA had significantly $(p<0.01)$ inhibited cell proliferation after $48 \mathrm{~h}$. By increasing the concentration of CO and CGA, the difference between the cell inhibition percentages of the cell lines were also increased. IQ displayed significantly $(p<0.01)$ strong antiproliferative activity against SUIT-2 cells at the lowest concentration $(30 \mu \mathrm{M})$ compared with A-375 and AGS cells, which showed significant $(p<0.01)$ effects at $125 \mu \mathrm{M}$.

The median inhibitory concentrations $\left(\mathrm{IC}_{50}\right)$ of $\mathrm{CO}, \mathrm{CGA}$, and IQ in the cell lines studied are summarized in Table 1 . To inhibit $50 \%$ of the total cell growth of AGS, A-375, and SUIT-2 cancer cell lines, the concentration of CO must be $2.54,4.05$, and $6.47 \mathrm{mg} / \mathrm{mL}$, respectively. Statistically, $\mathrm{CO}$ showed significant antiproliferative activities against AGS $(p<0.001)$ and A-375 $(p<0.01)$ cancer cells. CGA, on the other hand, had IC 50 values that ranged from 306.64 to $373.53 \mu \mathrm{M}$. No significant difference was observed between the cell lines. Lastly, IQ had a low $\mathrm{IC}_{50}$ value $(144.45 \mu \mathrm{M})$ for SUIT-2, implying that this cell line is more sensitive to IQ than the A-375 and AGS cells. The data show that IQ exhibits significant antiproliferative activity on SUIT-2 $(p<0.05)$ when compared to that on the other cell lines. 


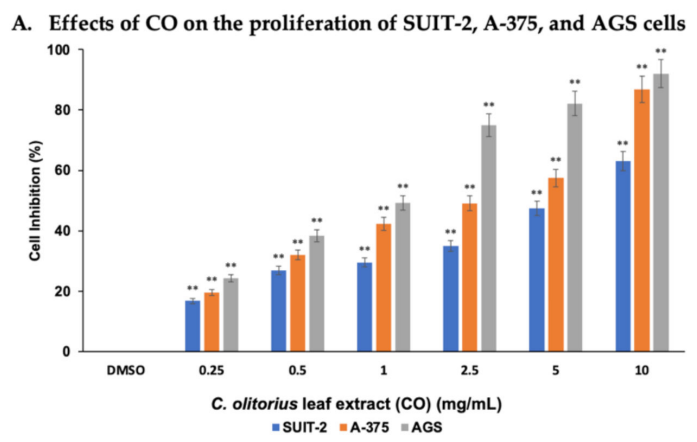

B. Effects of CGA on the proliferation of SUIT-2, A-375, and AGS cells

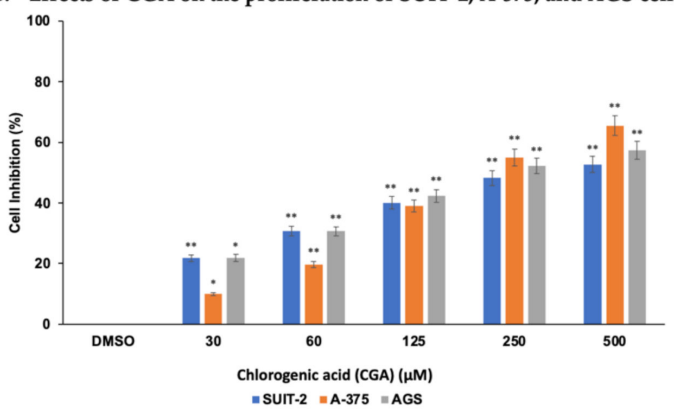

C. Effects of IQ on the proliferation of SUIT-2, A-375, and AGS cells

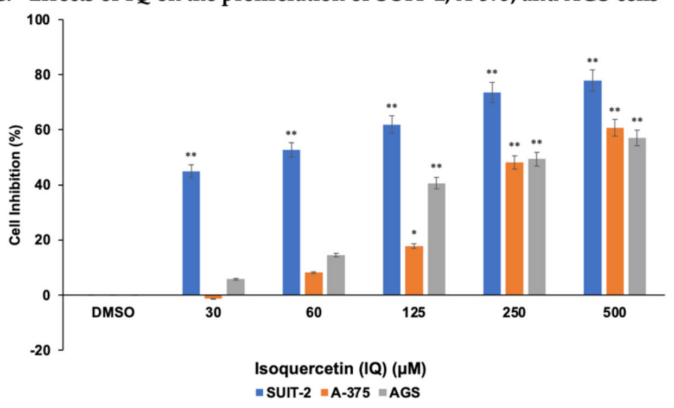

Figure 2. CO, CGA, and IQ induced antiproliferative activities in human cancer cells in the MTT assay $(\mathbf{A}-\mathbf{C})$ after $48 \mathrm{~h}$. Data are represented as mean $\pm \operatorname{SEM}(n=3)$. ${ }^{*} p<0.05$ or ${ }^{* *} p<0.01$ as compared to $0.5 \%$ DMSO treatment (control group).

Table 1. Median inhibitory concentration $\left(\mathrm{IC}_{50}\right)$ values of Corchorus olitorius aqueous extract, chlorogenic acid, and isoquercetin for SUIT-2, A-375, and AGS cancer cell lines.

\begin{tabular}{cccc}
\hline \multirow{2}{*}{ Treatment } & \multicolumn{3}{c}{ IC $_{\mathbf{5 0}}$ Values } \\
\cline { 2 - 4 } & SUIT-2 & A-375 & AGS \\
\hline CO $(\mathrm{mg} / \mathrm{mL})$ & $6.47 \pm 0.11^{\# \#}$ & $4.05 \pm 0.09^{* *}$ & $2.54 \pm 0.09^{* * *}$ \\
CGA $(\mu \mathrm{M})$ & $373.53 \pm 11.29^{\mathrm{ns}}$ & $306.64 \pm 20.83^{\mathrm{ns}}$ & $330.74 \pm 13.19^{\mathrm{ns}}$ \\
IQ $(\mu \mathrm{M})$ & $144.45 \pm 12.34^{\#}$ & $369.29 \pm 23.78^{*}$ & $355.97 \pm 19.93$ \\
\hline
\end{tabular}

The significance of the mean differences was assessed using one-way ANOVA. ${ }^{*} p<0.05,{ }^{* *} p<0.01$, and *** $p<0.001$ compared with SUIT-2 cells. ${ }^{\#} p<0.05$ and ${ }^{\# \#} p<0.01$ compared with A-375. ns No significant difference between groups.

\subsection{CO, CGA, and IQ Inhibit Angiogenesis and Tumor Growth in Ovo}

To determine the anti-angiogenic and antitumor activities of CO, CGA, IQ, and the combination of CGA and IQ, tumor implantations of A-375 and AGS cells were done in ovo using the CAM assay. The $\mathrm{Hb}$ levels and the weights of implanted A-375 or AGS tumors are presented in Figure 3. All treatments significantly $(p<0.001)$ suppressed angiogenesis of A375 and AGS tumors when compared to the control. However, only AGS was significantly $(p<0.001)$ inhibited by these treatments when compared to the control for tumor growth. 
Of note, CO significantly $(p<0.001)$ suppressed A-375 and AGS cancer progression, as expressed by their low $\mathrm{Hb}$ levels and tumor weights.
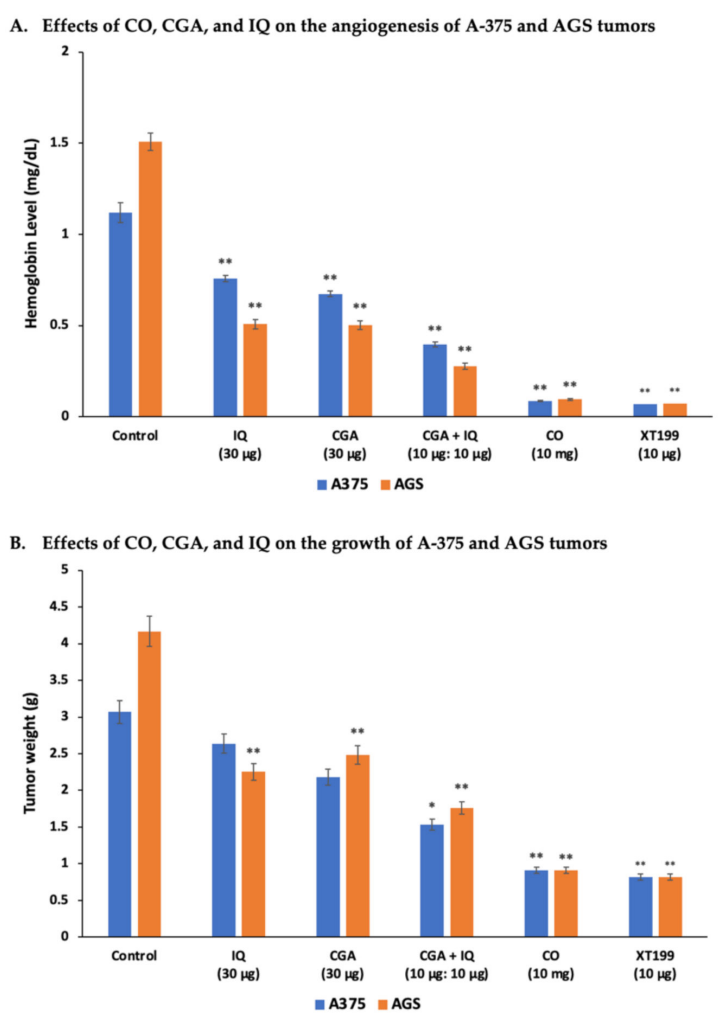

Figure 3. CO, CGA, IQ, and CGA + IQ inhibited angiogenesis and tumor growth of A-375 and AGS cancer cells. (A) Hemoglobin level measured from the CAM-implanted tumors after eight days. (B) Weight of the A-375 and AGS CAM tumors eight days after implantation and treatment. Data are represented as mean $\pm \operatorname{SEM}(n=3) .{ }^{*} p<0.01,{ }^{* *} p<0.001$ versus the control (untreated) group.

\section{Discussion}

Angiogenesis is a normal biological process that involves the formation of new blood vessels. This process plays an essential role in tumor growth by ensuring sufficient oxygen and nutrient supplies to cancer cells and tissues [6,7]. More often, tumors develop in tissues with dense lymphatic vascular networks and exploit pre-existing lymphatic vessels for invasion and metastasis [32]. Metastasis is considered a primary cause of mortality in cancer patients. Cancer cells break away from the primary tumor during this cellular process and move via blood or lymphatic vessels to proliferate and colonize lymph nodes and distant organs, forming new tumors [33]. Consequently, angiogenesis takes place to support the growing tumor.

One approach to finding agents to prevent cancer cell proliferation and tumor formation is to study natural agents sourced from nature. In Asia, C. olitorius is a common leafy vegetable widely used in preparing dishes [34] and traditional medicine [13,14]. Pharmacological studies have shown that $C$. olitorius exhibits promising antioxidant and anti-inflammatory activities [35] beneficial for treating different cancers [18]. Therefore, in this study, we evaluated the anticancer properties of $\mathrm{CO}$ and its bioactive compounds, namely CGA and IQ, against various human cancer cell lines. Our data revealed that CO has significant antiproliferative effects on SUIT-2, A-375, and AGS cells at a concentration as low as $2.54 \mathrm{mg} / \mathrm{mL}$.

Moreover, the results of the in ovo analysis showed that CO strongly inhibited angiogenesis and the growth of A-375 and AGS tumors. CO significantly prevented the formation of new blood vessels of tumors at $10 \mathrm{mg}$ per CAM by decreasing the supply of oxygen and essential nutrients they require. Due to limited oxygen and nutrient supplies, 
tumor growth of A-375 and AGS were effectively suppressed. Reports have shown that C. olitorius can activate procaspases-3 and 9, leading to a cleavage of the downstream substrate, poly (ADP-ribose) polymerase, followed by a downregulation of caspase-activated DNase signaling inhibition [36]. In a genotoxicity study, CO increased DNA damage in the nuclei of myeloma (ARH-77) cells [37]. These anticancer activities can be associated with the ability of $C$. olitorius to induce fragmentation of cancer DNA coupled with nuclear condensation-mediated apoptosis [36].

Consequently, nutraceutical products of $C$. olitorius, including CGA, also showed potent anticancer effects in human cancer. The data gathered in our study showed that $30 \mu \mathrm{M}$ CGA significantly prevented cancer cell proliferation after $48 \mathrm{~h}$ of incubation. Reports on the antiproliferative properties of CGA revealed that it could disrupt the cancer cell cycle and induce apoptosis [38-40] via increasing the expression of both Bax and caspase-3 genes and decreasing the level of B-cell lymphoma 2 (Bcl-2) [39]. Additionally, data gathered from CAM models showed that CGA has anti-angiogenic and antitumor properties against A-375 and AGS tumors. CGA at $30 \mu \mathrm{g} / \mathrm{CAM}$ significantly reduced the $\mathrm{Hb}$ level of the tumors by inhibiting the process of angiogenesis during eight days of treatment. However, the statistically significant antitumor activity of CGA was only observed in AGS tumors. Recent studies have shown that CGA can inhibit the cell growth of esophageal squamous cell carcinoma (ESCC), lung (A549), liver (AH109A), and kidney (A-498) cancer cell lines both through in vitro and in vivo models [40-43]. Zhan et al. reported that CGA could downregulate both BMI-1 oncogene and SOX-2 transcription factors in tumor tissues of ectopic xenograft tumors and carcinogen-induced ESCC models [41]. CGA was also found to induce apoptosis by upregulating the expression of both pro-apoptotic Bax and caspase-3 proteins and downregulating the level of the anti-apoptotic Bcl-2 protein in kidney (A-498) and lung (A549) cancer cells [39,40].

$\mathrm{IQ}$, a common flavonoid found in vegetables, is considered a good alternative for preventive therapy, or for supplementing the treatment of various diseases. In this study, data revealed that $30 \mu \mathrm{M}$ IQ significantly prevented cell proliferation of SUIT-2 after $48 \mathrm{~h}$ of incubation. IQ was also assessed to determine its antiangiogenic and antitumor effects on human melanoma and gastric cancer. Our results showed that IQ at $30 \mu \mathrm{g} / \mathrm{CAM}$ efficiently suppressed the angiogenesis and tumor growth of A-375 and AGS cancers implanted in CAMs. In 2014, a study conducted by Hara et al. showed that IQ successfully inhibited the growth of transplanted liver tumors in nude mice [44]. The same study found that IQ suppressed piperonyl butoxide-induced tumor promotion, potentiating PTEN/Akt and disrupting TGF- $\beta$ /Smad signaling pathways. Several studies have also revealed that IQ can activate caspase $-3,-8$, and -9 , thereby reducing the mitochondrial membrane potential of cancer cells [44,45]. IQ was found to inhibit the expression of ERK and p38 MAPK protein phosphorylation and reduce the expression level of protein kinase C (PKC), leading to the suppression of transplant liver tumors in nude mice [46].

Plant extracts are composed of different bioactive compounds. Thus, we combined CGA and IQ with a 1:1 ratio of $10 \mu \mathrm{g}$ of each compound per CAM to determine their interactions and influences on the anticancer properties of CO against A-375 and AGS tumors. Our data revealed that the combination of CGA and IQ provides synergistic anti-angiogenic and antitumor effects on both tumors. As shown by the low $\mathrm{Hb}$ levels of the tumors, the combination of CGA and IQ can significantly suppress the proliferation of new blood vessels, leading to the inhibition of tumor growth. Additionally, it was shown that the combination of CGA and IQ significantly contributed to the anticancer properties of $\mathrm{CO}$. Henceforth, there remains a need to further elucidate the anticancer properties of the remaining compounds present in $\mathrm{CO}$.

\section{Materials and Methods}

\subsection{Plant Collection and Authentication}

C. olitorius Linn leaves were collected at Sitio Basak in the Municipality of Tupi, South Cotabato, the Philippines. Plant samples were sent to the Bureau of Plant Industry (BPI) at 
the Department of Agriculture in Manila City, the Philippines, for proper authentication by a plant taxonomist. Legal documents such as export and local transport permits were secured from the BPI's satellite office in General Santos City, the Philippines. Experimentations, laboratory analyses, and documentation were conducted at the Pharmaceutical Research Institute of Albany College of Pharmacy and Health Sciences in Rensselaer City, New York, USA.

\subsection{Plant Preparation}

Approximately $5 \mathrm{~kg}$ of $C$. olitorius leaves was removed from their stems, washed with distilled water, and pat-dried using paper towels. The fresh leaves were brought to the Chemistry Analytical and Research Laboratory of the Ateneo de Davao University, Davao City, the Philippines for lyophilization using a HyperCOOL 3055 freeze dryer (Daejeon, South Korea) at $-55^{\circ} \mathrm{C}$ with $1 \times 10^{-3} \mathrm{~Pa}$ and grinding using an FSJ-1000A swing medicine milling machine (Henan Vic Machinery Co., Ltd., Zhengzhou, China) at 25,000 rpm with a \#60 sieve. Pulverized C. olitorius leaves were packed into seal-tight plastic bags with packets of silica gels. Bags were stored in a cool and dry place until further use.

\subsection{Plant Extraction}

Fifty grams of C. olitorius powder was boiled in distilled water (1 L) for $1 \mathrm{~h}$. After cooling, the plant sample was centrifuged $(13,419 \times g$ for $10 \mathrm{~min})$, and the highly viscous supernatant (gel-like, which suggests the presence of polysaccharides) was collected in a conical flask. The polysaccharides were precipitated by adding an equal volume of ethanol and stirring the sample at around $0{ }^{\circ} \mathrm{C}$ using ice. The precipitate was removed by centrifugation $(13,419 \times g$ for $10 \mathrm{~min})$, and the hydroalcoholic supernatant was recovered, filtered, and evaporated using a rotary evaporator. The viscous $C$. olitorius aqueous extract (CO) was stored in an amber vial and kept at $-20^{\circ} \mathrm{C}$ until further use.

\subsection{Solid-Phase Extraction}

CO $(1 \mathrm{mg} / \mathrm{mL})$ was prepared by dissolving the plant extract in distilled water. A solid-phase extraction vacuum manifold with Waters Sep-Pak C18 Vac Cartridge (Waters, Milford, MA, USA) was used to separate dissolved and suspended compounds present in the C. olitorius according to their physical and chemical properties. The column was pre-conditioned using $1 \mathrm{~mL}$ methanol followed by $1 \mathrm{~mL}$ distilled water. The C. olitorius was eluted using distilled water-methanol (1:1 ratio) as eluent. The eluant was collected and analyzed with LC-MS/MS to qualify and quantify its CGA and IQ contents.

\subsection{LC-MS/MS Analysis}

An API-4000 mass spectrometer (Sciex, Framingham, MA, USA), equipped with a Shimadzu UPLC system (Kyoto, Japan), was used for LC-MS/MS analyses. A Kinetex $2.6 \mu \mathrm{m}$ Polar C18 column $(50 \times 2.1 \mathrm{~mm}$, Phenomenex, Torrance, CA, USA) was used for reversed-phase separation. Mobile phases were: (A) water containing $0.1 \%$ formic acid and $5 \%$ acetonitrile, and (B) acetonitrile with $0.1 \%$ formic acid. The flow rate was $0.4 \mathrm{~mL} / \mathrm{min}$ and the gradient was linear, from 5\% B to $95 \%$ B, for 2.5-3 min. The oven temperature was $40{ }^{\circ} \mathrm{C}$ and the injection volume was $5 \mu \mathrm{L}$. Electro-spray ionization (ESI) was used in negative MRM mode. CGA and IQ were purchased from Sigma-Aldrich (St. Louis, MO, USA). Mass transitions for phytochemicals were: Q1/Q3: 352.9/190.8 (CGA); 463.0/299.9 (IQ). The operative parameters of the mass spectrometer for CGA and IQ were as follows: decluttering potentials (DP): -45 and $-85 \mathrm{~V}$; entrance potentials (EP): $-10 \mathrm{~V}$; collision energies (CE): -24 and $-36 \mathrm{eV}$; collision cell exit potential (CXP): $-17 \mathrm{~V}$; curtain gas (CUR): 50 psi; gas 1 (GS1, nebulizer gas): 50 psi; gas 2 (GS2, heater gas): 30 psi; ion spray voltage (IS): $-4500 \mathrm{~V}$; temperature (TEM): $500{ }^{\circ} \mathrm{C}$; collision activate dissociation (CAD) gas: -12 psi; dwell time: $150 \mathrm{~ms}$. Nitrogen was used for the gases. Standard curves were obtained using standard solutions of CGA with concentrations of 200, 100, 50, 20, 10 , and $1 \mathrm{ng} / \mathrm{mL}$ and IQ with concentrations of $1000,500,250,100,50$, and $5 \mathrm{ng} / \mathrm{mL}$. The 
LC-MS/MS methods for CGA and IQ were linear $(r=0.9979$ and 0.9975) within the ranges of standard solutions.

\subsection{Cell Culture}

Human pancreatic (SUIT-2) (MD Anderson Cancer Center, Houston, TX, USA), melanoma (A-375), and gastric (AGS) cancer cells (ATTC, Manassas, VA, USA) were maintained in Roswell Park Memorial Institute 1640 (RPMI-1640) growth medium supplemented with $10 \%$ fetal bovine serum, $100 \mathrm{IU} / \mathrm{mL}$ penicillin, $100 \mathrm{mg} / \mathrm{mL}$ streptomycin, and $2 \mathrm{mM}$ L-glutamine purchased from Sigma-Aldrich. Cultures were maintained in a $37^{\circ} \mathrm{C}$ humidified chamber with $5 \% \mathrm{CO}_{2}$. Media were changed every three days, and the cell lines were passaged at $80 \%$ confluence.

\subsection{3-(4, 5-Dimethyl thiazolyl-2)-2, 5-Diphenyltetrazolium Bromide (MTT) Assay}

Briefly, SUIT-2, A-375, and AGS cancer cells were seeded at a density of $10^{4}$ cells/well in 96-well plates and incubated for $24 \mathrm{~h}$ at $37^{\circ} \mathrm{C}$. After removing the cell culture media, cells were exposed to different concentrations of $\mathrm{CO}(0$ to $400 \mu \mathrm{g} / \mathrm{mL})$ and its bioactive compounds, CGA and IQ (0 to $500 \mu \mathrm{M})$ prepared in the RPMI-1640 media. The cells were then incubated for $48 \mathrm{~h}$, and cytotoxicity was assessed using tetrazolium salt reduction (MTT assay) [47]. Treatments were completely aspirated from each well and replaced with a $110 \mu \mathrm{L}$ MTT solution $(0.5 \mathrm{mg} / \mathrm{mL})$. The plates were covered with tin foil and incubated for another $4 \mathrm{~h}$ at $37^{\circ} \mathrm{C}$. The formazan crystals produced by living cells were solubilized by removing $80 \mu \mathrm{L}$ of MTT solution and by adding $50 \mu \mathrm{L}$ of dimethyl sulfoxide (DMSO) in each well. The optical density of each well was determined at $570 \mathrm{~nm}$ using an ELISA microplate reader. Untreated cells were used as a negative control. The cell viability percentage was calculated by considering the negative control as $100 \%$. All the experiments were performed in triplicate.

\subsection{Tumor Growth and Angiogenesis in the Chorioallantoic Membrane Model}

One-day-old chick embryos were purchased from Charles River (Norwich, CT, USA) and maintained at $37{ }^{\circ} \mathrm{C}$ and $55 \%$ relative humidity. After seven days of incubation, the CAM assay was performed, as previously described [48]. In brief, a hypodermic needle was used to make a small hole in the blunt end of the eggshell, with a second hole then made on the broad side of the egg over an avascular portion of the embryonic membrane. Slight suction was applied to the first hole to displace the air sac and drop the CAM away from the shell. Using a Dremel drill (Racine, WI, USA), a window $\left(1 \mathrm{~cm}^{2}\right)$ was cut in the shell over the false air sac, allowing access to the CAM. Either A-375 or AGS cells $\left(1 \times 10^{6}\right)$ were mixed in Matrigel and implanted on the CAM. Treatments were applied: CO $(10 \mathrm{mg})$, CGA $(30 \mu \mathrm{g}), \mathrm{IQ}(30 \mu \mathrm{g})$, CGA-IQ combination $(10 \mu \mathrm{g}: 10 \mu \mathrm{g})$, and an integrin $\alpha v \beta 3$ antagonist, XT199 (positive control). The antitumor activities of the treatments on tumor angiogenesis and growth were determined 8 days later. A-375 and AGS tumors were extracted by cutting tumors from the CAM and placing them in Eppendorf tubes. Each tumor was weighed using an analytical balance.

Tumor hemoglobin $(\mathrm{Hb})$ content was indexed as a measure of tumor vascularity [32]. In brief, tumor sections were homogenized for 5-10 $\mathrm{min}$ in double-distilled water. The samples were centrifugated at $2147 \times g$ for $10 \mathrm{~min}$, and the supernatant was used for $\mathrm{Hb}$ analysis. Drabkin's reagent was added to the supernatant, and $\mathrm{Hb}$ absorbance was measured at $540 \mathrm{~nm}$ with an ELISA microplate reader. $\mathrm{Hb}$ concentration was expressed as $\mathrm{mg} / \mathrm{mL}$ based on comparison with a standard curve. Data represent the mean $\pm \mathrm{SEM}$ of tumor weight (in grams) per treatment group and tumor $\mathrm{Hb}$ (in $\mathrm{mg} / \mathrm{dL}$ ), where $n=5$ per group.

\section{Conclusions}

This study is the first to establish that CO and its bioactive compounds CGA and IQ can inhibit the proliferation of various human cancer cells in vitro and suppress the growth of A-375 and AGS tumor xenografts in ovo in a CAM model by inducing apoptosis 
and anti-angiogenetic properties. Taken together, the anticancer activities of $\mathrm{CO}$ and its bioactive compounds can be associated with their capacity to regulate various proteins and signaling pathways in order to induce DNA damage in cancer cells. Therefore, CO, CGA, and IQ may have the potential to be developed clinically as novel anticancer agents.

Author Contributions: Conceptualization, J.P.S.T., O.M.N. and S.A.M.; data curation, J.P.S.T.; formal analysis, J.P.S.T., T.S., N.H.E.D. and S.A.M.; funding acquisition, J.P.S.T.; investigation, J.P.S.T., T.S., N.H.E.D. and S.A.M.; methodology, J.P.S.T., T.S., N.H.E.D. and S.A.M.; project administration, J.P.S.T., O.M.N. and S.A.M.; resources, J.P.S.T., O.M.N. and S.A.M.; supervision, J.P.S.T., O.M.N., T.S., N.H.E.D. and S.A.M.; validation, J.P.S.T., T.S., N.H.E.D. and S.A.M.; visualization, J.P.S.T., T.S., N.H.E.D. and S.A.M.; writing—original draft, J.P.S.T.; writing—review and editing, J.P.S.T., O.M.N., T.S., N.H.E.D. and S.A.M. All authors have read and agreed to the published version of the manuscript.

Funding: This work was supported by a grant from the Department of Science and TechnologyAccelerated Science and Technology Human Resource Development Program (DOST-ASTHRDP) of the Philippines to J.P.S.T.

Institutional Review Board Statement: Not applicable.

Informed Consent Statement: Not applicable.

Data Availability Statement: Not applicable.

Acknowledgments: We thank Manuel D. Ching (chief of the Crop Research and Production Support Division of the Bureau of Plant Industry, Department of Agriculture, the Philippines) for identifying, authenticating, and certifying the plant specimen. The authors would like to thank Kazutoshi Fujioka for sharing his expertise in compound identification and quantification using LC-MS/MS analysis. We would also like to acknowledge Kelly Keating of the Pharmaceutical Research Institute for editing the manuscript.

Conflicts of Interest: No competing financial interests exist. The authors declare the absence of other types of conflict of interest.

Sample Availability: Not available.

\section{References}

1. Jubb, A.M.; Oates, A.J.; Holden, S.; Koeppen, H. Predicting benefit from anti-angiogenic agents in malignancy. Nat. Rev. Cancer 2006, 6, 626-635. [CrossRef] [PubMed]

2. Kerbel, R.; Folkman, J. Clinical translation of angiogenesis inhibitors. Nat. Rev. Cancer 2002, 2, 727-739. [CrossRef] [PubMed]

3. Kunimasa, K.; Ohta, T.; Tani, H.; Kato, E.; Eguchi, R.; Kaji, K.; Ikeda, K.; Mori, H.; Mori, M.; Tatefuji, T.; et al. Resveratrol derivative-rich melinjo (Gnetum gnemon L.) seed extract suppresses multiple angiogenesis-related endothelial cell functions and tumor angiogenesis. Mol. Nutr. Food Res. 2011, 55, 1730-1734. [CrossRef]

4. Lam, I.K.; Alex, D.; Wang, Y.-H.; Liu, P.; Liu, A.-L.; Du, G.-H.; Lee, S.M. In vitro and in vivo structure and activity relationship analysis of polymethoxylated flavonoids: Identifying sinensetin as a novel antiangiogenesis agent. Mol. Nutr. Food Res. 2012, 56, 945-956. [CrossRef]

5. Piao, X.-M.; Gao, F.; Zhu, J.-X.; Wang, L.-J.; Zhao, X.; Li, X.; Sheng, M.-M.; Zhang, Y. Cucurbitacin B inhibits tumor angiogenesis by triggering the mitochondrial signaling pathway in endothelial cells. Int. J. Mol. Med. 2018, 42, 1018-1025. [CrossRef]

6. Tabata, Y. Tissue regeneration based on growth factor release. Tissue Eng. 2003, 9, 5-15. [CrossRef]

7. Zhu, L.; Niu, G.; Fang, X.; Chen, X. Preclinical molecular imaging of tumor angiogenesis. Q. J. Nucl. Med. Mol. Imaging 2010, 54, 291-308. [PubMed]

8. Kerbel, R.S. Tumor angiogenesis. N. Engl. J. Med. 2008, 358, 2039-2049. [CrossRef]

9. Verheul, H.; Voest, E.; Schlingemann, R.O. Are tumours angiogenesis-dependent? J. Pathol. 2004, 202, 5-13. [CrossRef]

10. Shibuya, M. Structure and function of VEGF/VEGF-receptor system involved in angiogenesis. Cell Struct. Funct. 2001, 26, 25-35. [CrossRef]

11. Ferrara, N. Vascular endothelial growth factor: Basic science and clinical progress. Endocr. Rev. 2004, 25, 581-611. [CrossRef]

12. DOST-Department of Science and Technology. Harmonized National R\&D Agenda (HNRDA) 2017-2022. Available online: http:/ / dost.gov.ph/phocadownload/Downloads/Journals / Approved\%20Harmonized\%20National\%20RD\%20Agenda\% 20\%202017-2022.pdf (accessed on 10 October 2018).

13. Oboh, G.; Ademiluyi, A.O.; Akinyemi, A.; Henle, T.; Saliu, J.A.; Schwarzenbolz, U. Inhibitory effect of polyphenol-rich extracts of jute leaf (Corchorus olitorius) on key enzyme linked to type 2 diabetes ( $\alpha$-amylase and $\alpha$-glucosidase) and hypertension (angiotensin I converting) in vitro. J. Funct. Foods 2012, 4, 450-458. [CrossRef] 
14. Zakaria, Z.; Sulaiman, M.; Arifah, A.; Jais, A.M.; Somchit, M.; Kirisnaven, K.; Punnitharr, D.; Safarul, M.; Fatimah, C.; Johari, R. The anti-inflammatory and antipyretic activities of corchorus olitorius in rats. J. Pharmacol. Toxicol. 2006, 1, 139-146. [CrossRef]

15. Soladoye, M.O.; Chukwuma, E.C.; Feyisola, R.T. Ethnobotanical survey of plants used in the traditional treatment of female infertility in Southwestern Nigeria. Ethnobot. Res. Appl. 2014, 12, 81-90.

16. Barku, V.Y.A.; Boye, A.; Quansah, N. Antioxidant and wound healing studies on the extracts of Corchorus olitorius leaf. World Essay J. 2013, 1, 67-73.

17. Owoyele, B.; Oyewole, A.L.; Alimi, M.L.; Sanni, S.A.; Oyeleke, S.A. Anti-inflammatory and antipyretic properties of Corchorus olitorius aqueous root extract in Wistar rats. J. Basic Clin. Physiol. Pharmacol. 2015, 26, 363-368. [CrossRef]

18. Abdel-Wahhab, M.A.; Ibrahim, M.I.M.; Pieters, R.; van der Walt, A.M.; Abdel-Aziem, S.H.; Bezuidenhout, C.C.; Giesy, J.P. Aqueous extract of Corchorus olitorius decreases cytotoxicity of aflatoxin B1and fumonisin B1in H4IIE-luc cells. Hepatoma Res. 2015, 1, 75-85. [CrossRef]

19. Appleton, J. Evaluating the bioavailability of isoquercetin. Nat. Med. J. 2010, 2, 1-6.

20. Yoshikawa, M.; Shimada, H.; Saka, M.; Yoshizumi, S.; Yamahara, J.; Matsuda, H. Medicinal foodstuffs. V. Moroheiya (1): Absolute stereostructures of corchoionosides A, B, and C, histamine inhibitors from the leaves of Vietnamese Corchorus olitorius L. (Tiliaceae). Chem. Pharm. Bull. 1997, 45, 464-469. [CrossRef]

21. Nardini, M.; Cirillo, E.; Natella, F.; Scaccini, C. Absorption of phenolic acids in humans after coffee consumption. J. Agric. Food Chem. 2002, 50, 5735-5741. [CrossRef]

22. Liang, N.; Kitts, D.D. Role of chlorogenic acids in controlling oxidative and inflammatory stress conditions. Nutrients 2015, 8, 16 . [CrossRef]

23. Jiang, Y.; Satoh, K.; Kusama, K.; Watanabe, S.; Sakagami, H. Interaction between chlorogenic acid and antioxidants. Anticancer Res. 2000, 20, 2473-2476. [PubMed]

24. Yagasaki, K.; Miura, Y.; Okauchi, R.; Furuse, T. Inhibitory effects of chlorogenic acid and its related compounds on the invasion of hepatoma cells in culture. Cytotechnology 2000, 33, 229-235. [CrossRef] [PubMed]

25. Belkaid, A.; Currie, J.-C.; Desgagnés, J.; Annabi, B. The chemopreventive properties of chlorogenic acid reveal a potential new role for the microsomal glucose-6-phosphate translocase in brain tumor progression. Cancer Cell Int. 2006, 6, 7. [CrossRef]

26. Noratto, G.; Porter, W.; Byrne, D.; Cisneros-Zevallos, L. Identifying peach and plum polyphenols with chemopreventive potential against estrogen-independent breast cancer cells. J. Agric. Food Chem. 2009, 57, 5219-5226. [CrossRef] [PubMed]

27. Liu, Y.-J.; Zhou, C.-Y.; Qiu, C.-H.; Lu, X.-M.; Wang, Y.-T. Chlorogenic acid induced apoptosis and inhibition of proliferation in human acute promyelocytic leukemia HL-60 cells. Mol. Med. Rep. 2013, 8, 1106-1110. [CrossRef]

28. Nishimura, J.; Saegusa, Y.; Dewa, Y.; Jin, M.; Kawai, M.; Kemmochi, S.; Harada, T.; Hayashi, S.M.; Shibutani, M.; Mitsumori, K. Antioxidant enzymatically modified isoquercitrin or melatonin supplementation reduces oxidative stress-mediated hepatocellular tumor promotion of oxfendazole in rats. Arch. Toxicol. 2010, 84, 143-153. [CrossRef] [PubMed]

29. Emura, K.; Yokomizo, A.; Toyoshi, T.; Moriwaki, M. Effect of enzymatically modified isoquercitrin in spontaneously hyper-tensive rats. J. Nutr. Sci. Vitaminol. 2007, 53, 68-74. [CrossRef]

30. De Araújo, M.E.M.B.; Franco, Y.E.M.; Alberto, T.G.; Sobreiro, M.A.; Conrado, M.A.V.; Priolli, D.G.; Sawaya, A.; Ruiz, A.L.T.G.; de Carvalho, J.E.; de Carvalho, P. Enzymatic de-glycosylation of rutin improves its antioxidant and antiproliferative activities. Food Chem. 2013, 141, 266-273. [CrossRef]

31. You, H.J.; Ahn, H.J.; Ji, G.E. Transformation of rutin to antiproliferative quercetin-3-glucoside by aspergillus niger. J. Agric. Food Chem. 2010, 58, 10886-10892. [CrossRef] [PubMed]

32. Jones, D. Parallels of resistance between angiogenesis and lymphangiogenesis inhibition in cancer therapy. Cells 2020, 9, 762. [CrossRef]

33. NCI-National Cancer Institute. Metastasis. Available online: https://www.cancer.gov/publications/dictionaries/cancerterms / def/metastasis (accessed on 10 October 2018).

34. Loumerem, M.; Alercia, A. Descriptors for jute (Corchorus olitorius L.). Genet. Resour. Crop Evol. 2016, 63, 1103-1111. [CrossRef]

35. Handoussa, H.; Hanafi, R.; Eddiasty, I.; El-Gendy, M.; El Khatib, A.; Linscheid, M.; Mahran, L.; Ayoub, N. Anti-inflammatory and cytotoxic activities of dietary phenolics isolated from corchorus olitorius and vitis vinifera. J. Funct. Foods 2013, 5, 1204-1216. [CrossRef]

36. Li, C.-J.; Huang, S.-Y.; Wu, M.-Y.; Chen, Y.-C.; Tsang, S.-F.; Chyuan, J.-H.; Hsu, H.-Y. Induction of apoptosis by ethanolic extract of corchorus olitorius leaf in human hepatocellular carcinoma (HepG2) cells via a mitochondria-dependent pathway. Molecules 2012, 17, 9348-9360. [CrossRef]

37. Işeri, D.; Yurtcu, E.; Sahin, F.I.; Haberal, M. Corchorus olitorius(jute) extract induced cytotoxicity and genotoxicity on human multiple myeloma cells (ARH-77). Pharm. Biol. 2013, 51, 766-770. [CrossRef]

38. Deka, S.J.; Gorai, S.; Manna, D.; Trivedi, V. Evidence of PKC binding and translocation to explain the anticancer mechanism of chlorogenic acid in breast cancer cells. Curr. Mol. Med. 2017, 17, 79-89. [CrossRef]

39. Sarkate, A.; Banerjee, S.; Mir, J.I.; Roy, P.; Sircar, D. Antioxidant and cytotoxic activity of bioactive phenolic metabolites isolated from the yeast-extract treated cell culture of apple. Plant Cell Tissue Organ Cult. 2017, 130, 641-649. [CrossRef]

40. Wang, X.; Liu, J.; Xie, Z.; Rao, J.; Xu, G.; Huang, K.; Li, W.; Yin, Z. Chlorogenic acid inhibits proliferation and induces apoptosis in A498 human kidney cancer cells via inactivating PI3K/Akt/mTOR signalling pathway. J. Pharm. Pharmacol. 2019, 71, 1100-1109. [CrossRef] 
41. Zhan, Y.; Li, R.; Feng, C.; Li, X.; Huang, S.; Wang, L.; Liu, Z.; Jiang, J.; Han, Y. Chlorogenic acid inhibits esophageal squamous cell carcinoma growth in vitro and in vivo by downregulating the expression of BMI1 and SOX. Biomed. Pharmacother. 2020, 121, 109602. [CrossRef] [PubMed]

42. Yamagata, K.; Izawa, Y.; Onodera, D.; Tagami, M. Chlorogenic acid regulates apoptosis and stem cell marker-related gene expression in A549 human lung cancer cells. Mol. Cell. Biochem. 2018, 441, 9-19. [CrossRef]

43. Weng, C.-J.; Yen, G.-C. Chemopreventive effects of dietary phytochemicals against cancer invasion and metastasis: Phenolic acids, monophenol, polyphenol, and their derivatives. Cancer Treat. Rev. 2012, 38, 76-87. [CrossRef] [PubMed]

44. Hara, S.; Morita, R.; Ogawa, T.; Segawa, R.; Takimoto, N.; Suzuki, K.; Hamadate, N.; Hayashi, S.-M.; Odachi, A.; Ogiwara, I.; et al. Tumor suppression effects of bilberry extracts and enzymatically modified isoquercitrin in early preneoplastic liver cell lesions induced by piperonyl butoxide promotion in a two-stage rat hepatocarcinogenesis model. Exp. Toxicol. Pathol. 2014, 66, 225-234. [CrossRef]

45. Chen, Q.; Li, P.; Xu, Y.; Li, Y.; Tang, B. Isoquercitrin inhibits the progression of pancreatic cancer in vivo and in vitro by regulating opioid receptors and the mitogen-activated protein kinase signalling pathway. Oncol. Rep. 2015, 33, 840-848. [CrossRef] [PubMed]

46. Huang, G.; Tang, B.; Tang, K.; Dong, X.; Deng, J.; Liao, L.; Liao, Z.; Yang, H.; He, S. Isoquercitrin inhibits the progression of liver cancer in vivo and in vitro via the MAPK signalling pathway. Oncol. Rep. 2014, 31, 2377-2384. [CrossRef]

47. Siddiqui, I.A.; Malik, A.; Adhami, V.M.; Asim, M.; Hafeez, B.B.; Sarfaraz, S.; Mukhtar, H. Green tea polyphenol EGCG sensitizes human prostate carcinoma LNCaP cells to TRAIL-mediated apoptosis and synergistically inhibits biomarkers associated with angiogenesis and metastasis. Oncogene 2008, 27, 2055-2063. [CrossRef] [PubMed]

48. Sudha, T.; Yalcin, M.; Lin, H.-Y.; Elmetwally, A.M.; Nazeer, T.; Arumugam, T.; Phillips, P.; Mousa, S.A. Suppression of pancreatic cancer by sulfated non-anticoagulant low molecular weight heparin. Cancer Lett. 2014, 350, 25-33. [CrossRef] 